\section{Recombinant DNA experiments to remain under safety guidelines}

There will be no major removal of experiments using recombinant DNA techniques from safety guidelines laid down by the National Institutes of Health, writes David Dickson

Last week the director of NIH, Dr Donald Fredrickson, proposed in response to a recommendation from the Institute's Recombinant DNA Advisory Committee (RAC) that physical containment levels for virtually all experiments using the disabled $\mathrm{K}-12$ strain of the bacterium Escherichia Coli should be reduced to the P1 level.

However he rejected the committee's suggestion that the experiments be formally exempted from the guidelines and hence from NIH enforcement proposing instead that they be placed in a special class which would still ensure that the containment requirements were met.

Dr Fredrickson's proposals were announced in the Federal Register last Friday (30 November) and follow a close scrutiny of the reasoning which led to the RAC's decision, taken by a vote of ten to four, with one abstention, at the committee's September meeting.

Rather than giving precise reasons for his decision, Dr Fredrickson lists the various events necessary for a serious accident to occur. In each case he quotes the opinion of scientists that the chance of such an occurrence is relatively low; and he points out that when a series of small probabilities are multipled together, the chance of a sequence of events is "exceedingly low".

On the question of whether $E$ coli could cause an epidemic by passing from one the conclusion of Dr Eugene Gangarosa, writing in a recent issue of the Journal of Infectious Disease that an epidemic "does not seem remotely possible".

Similarly in response to the question of whether $E$ coli $\mathrm{K}-12$ is pathogenic, Dr Fredrickson quotes Dr Sherwood Gorbach's conclusion that the disabled bacterium is intrinsically impaired in most, if not all, of a variety of virulence factors, all of which are required by a microorganism to produce disease.

Taken together, suggests $\mathrm{Dr}$ Fredrickson, this evidence is sufficient to reduce containment levels for the bacterium to P1. However he says that he is not proposing to exempt the experiments, since the term 'exempt experiment' as currently used in the guidelines "should only be used for experiments for which no containment level is specified and for which no registration with the IBC is required".

As an alternative, Dr Fredrickson has proposed creating a special class within the guidelines for experiments using $E$ coli $\mathrm{K}-12$, except for otherwise exempt or prohibited experiments, or as otherwise specified. Experiments in this class would require $P 1$ containment including a ban on person to another, for example, he quotes mouth pipetting and the requirement that all biological wastes are decontaminated.

"For these experiments no memorandum of understanding and agreement ... need be submitted, nor is any registration with NIH necessary." However, suggests Dr Fredrickson, for these experiments, prior to their initiation, investigators must submit to their institutional biosafety committee a registration document that contains a description of:

- the source(s) of DNA,

- the nature of the inserted DNA sequences, and

- the hosts and vectors to be used.

The IBC will review all such proposals submitted by investigators, although such review will not be required prior to initiation of experiments. An exception, however, requiring both prior review and approval by the IBC is any experiment in which there is a deliberate attempt to have the $E$ coli $\mathrm{K}-12$ efficiently express any gene coding for a eukaryotic protein.

Elsewhere in this proposed revision to the guidelines, Dr Fredrickson repeats his proposal to introduce a new section covering in detail the way in which private companies can register their experiments with the NIH and submit them where necessary for approval to the RAC, but on a voluntary basis.

Dr Fredrickson says that a number of objections to this process have been received by $\mathrm{NIH}$, claiming a voluntary system of regulation to be inadequate. However he also points out that the RAC voted by 11 to none, with four abstentions, in favour of these proposals, and says that he is therefore intending to include them in the revised guidelines.

\title{
US legislators reject moratorium on nuclear power
}

In its first significant vote on nuclear power since the Three Mile Island accident last March, the US House of Representatives last week rejected by 254 votes to 135 a proposal that the Nuclear Regulatory Commission be required to impose a sixmonth moratorium on issuing construction permits for new nuclear power plants.

In a similar vote last July, the Senate had also rejected a moratorium proposed by Senator Edward Kennedy by 57 votes to 35 . Since then, however, a national poll has shown $57 \%$ of those interviewed to favour such a move - and supporters of the moratorium were therefore disappointed not to have done better in the House vote, where they had hoped to pick up considerably more supporters.

The moratorium proposals have been the major focus of public debate since the TMI accident, much of it symbolic since the NRC has itself announced that it will not grant any new permits until it has absorbed the conclusions of the President's Commission of Inquiry, chaired by $\mathrm{Dr}$ John Kemeny.
In presenting the Commission's report last month, Dr Kemeny said that eight out of the 12 members of the Commission had favoured a moratorium of some kind; but no more than six - less than the needed majority - could agree on specific conditions under which a moratorium would be terminated.

Last week's proposal was put to the House by Representative Edward Markey, a Democrat from a working-class district of Boston, who argued that it was not meant to be a pro-nuclear or an antinuclear statement, but merely to signify that nuclear power should be made safe.

The TMI accident demonstrated that the regulatory framework had failed, and fundamental reforms were needed to make nuclear power safe. The amendment "would send a message loudly and clearly to the industry and the Nuclear Regulatory Commission that Congress will no longer tolerate any future corner-cutting in the area of nuclear safety", Mr Markey said.

Opponents of the moratorium, however, argued that it was unlikely to have any significant effect - and that recent events in Iran had underlined the need for nuclear power to reduce dependence on foreign oil.

"The passage of the Markey amendment would be used by certain sectors of the media to dramatically harm public confidence in nuclear energy all across the world in the same way that they use the TMI accident to sensationalise and exaggerate nuclear hazards", said Mr Mike McCormack, chairman of the House Science Committee's Energy Subcommittee.

After the amendment had been defeated, Mr Markey said he still felt it was a good beginning "considering the 25 years of lobbying for nuclear energy and the very intensive effort by the utilities and the reactor manufacturers during the past few weeks".

In contrast $\mathrm{Mr}$ Carl Walske, President of the Atomic Industry Forum, said: "We think the House sent a very good message to the Ayatollah in voting it down". 